\title{
NOTES
}

\section{Leuconostoc mesenteroides subsp. cremoris (Knudsen and Sørensen) comb. nov. and Leuconostoc mesenteroides subsp. dextranicum (Beijerinck) comb. nov.}

\author{
ELLEN I. GARVIE
}

National Institute for Research in Dairying, Shinfield, Reading RG2 9AT, England

\begin{abstract}
Leuconostoc mesenteroides (Tsenkovskii) van Tieghem 1878, Leuconostoc dextranicum (Beijerinck) Hucker and Pederson 1930, and Leuconostoc cremoris (Knudsen and Sørensen) Garvie 1960 belong to a single deoxyribonucleic acid homology group. These three organisms have similar lactate dehydrogenases and glucose-6-phosphate dehydrogenases. Because of these common properties, these organisms are here regarded as subspecies within a single species, Leuconostoc mesenteroides. The names of the subspecies are Leuconostoc mesenteroides subsp. mesenteroides, Leuconostoc mesenteroides subsp. dextranicum (Beijerinck) comb. nov, , and Leuconostoc mesenteroides subsp. cremoris (Knudsen and Sørensen) comb. nov. The type strains of these subspecies are ATCC 8293, NCDO 529, and NCDO 543, respectively.
\end{abstract}

The concept that a single species, Leuconostoc mesenteroides, should include as subspecies the bacteria previously classified as $L$. mesenteroides, Leuconostoc dextranicum, and Leuconostoc cremoris, has been suggested previously $(2,7)$. These species form a single deoxyribonucleic acid (DNA) homology group despite large differences in physiological properties (1). DNA-DNA homologies have been estimated by the membrane filter technique (2) and by the hydroxyapatite method (7). Both of these studies used the type strains. L. mesenteroides NCDO $523^{\mathrm{T}}$ (type strain) had $110 \pm 9.3 \%$ DNA homology with $L$. dextranicum NDCO $529^{\mathrm{T}}$ and $66 \pm 10.3 \%$ with $L$. cremoris NCDO $543^{\mathrm{T}}$ (2). The homology values were 90 and $78 \%$, respectively, when hydroxyapatite was used (7).

The immunological relationships among the lactate dehydrogenases and among the glucose6-phosphate dehydrogenases of the leuconostocs have been determined $(4,6)$. On this basis, it was found that L. mesenteroides (most strains), $L$. dextranicum, and $L$. cremoris constituted a single group distinct from Leuconostoc lactis, Leuconostoc paramesenteroides, and Leuconostoc oenos, thus supporting the division of the genus based on DNA homology.

Recently, other authors have argued that a DNA homology group forms a bacterial species and have divided the Lactobacillus acidophilus group into several species based on DNA homology groups $(8,10)$. The same species concept has been used for other genera $(5,11,12)$.
As phenotypically similar strains are placed in different species on the basis of low DNA homology and different compositions of enzyme proteins, conversely, phenotypically different strain NCDO 523, is in the group of strains that shows high DNA-DNA homology with the type form single genospecies.

Hontebeyrie and Gasser (7) have suggested that $L$. mesenteroides may require subdividing. However, the type strain of $L$. mesenteroides, strain NCDO 523, is in the group of strains that shows high DNA-DNA homology with the type strains of $L$. dextranicum and $L$. cremoris. On the basis of priority, the name L. mesenteroides must remain with this group even if new species are defined subsequently.

At present, there is no explanation for why bacteria showing wide phenotypic differences have high DNA homology. DNA homology techniques measure chromosomal DNA, and it appears that much of the information carried in the $L$. cremoris chromosome is suppressed. Plasmids may be involved, but their role, if any, must await clarification until there is an understanding of the function of plasmids in bacteria living under natural conditions. The differences between the proposed subspecies are stable and many. It appears unlikely that these differences are all individually encoded in plasmids.

The decision to propose subspecies status for $L$. dextranicum and $L$. cremoris was made because the distinctions among the three proposed subspecies are large. L. cremoris is an important 
dairy starter organism. The differences between $L$. cremoris and the other two species, L. mesenteroides and $L$. dextranicum, are important to the dairy industry. The names of the proposed subspecies are Leuconostoc mesenteroides subsp. dextranicum (Beijerinck) comb. nov. and L. mesenteroides subsp. cremoris (Knudsen and Sørensen) comb. nov.; according to rule 46 of the International Code of Nomenclature of Bacteria (9), the valid publication of these subspecies names automatically creates the subspecies L. mesenteroides subsp. mesenteroides. The type strains of these subspecies are NCDO 529, NCDO 543, and ATCC 8293, respectively. The properties of these type strains have been described recently $(2,3)$.

\section{LITERATURE CITED}

1. Garvie, E. I. 1974. Genus Leuconostoc, p. 510-513. In R. E. Buchanan and N. E. Gibbons (ed.), Bergey's manual of determinative bacteriology, 8 th ed. The Williams \& Wilkins Co., Baltimore.

2. Garvie, E. I. 1976. Hybridization between the deoxyribonucleic acids of some strains of heterofermentative lactic acid bacteria. Int. J. Syst. Bacteriol. 26:116-122 .

3. Garvie, E. I. 1979. Proposal of neotype strains for Leuconostoc mesenteroides (Tsenkovskii) van Tieghem, Leuconostoc dextranicum (Beijerinck) Hucker and Pederson, and Leuconostoc cremoris (Knudsen and Sørensen) Garvie. Int. J. Syst. Bacteriol. 29:149-151.

4. Gasser, F., and M. Hontebeyrie. 1977. Immunological relationships of glucose-6-phosphate dehydrogenase of
Leuconostoc mesenteroides NCDO 768 (= ATCC 12291). Int. J. Syst. Bacteriol. 27:6-8.

5. Harvey, S., and M. J. Pickett. 1980. Comparison of adansonian analysis and deoxyribonucleic acid hybridization results in the taxonomy of Yersinia entercolitica. Int. J. Syst. Bacteriol. 30:82-102.

6. Hontebeyrie, M., and F. Gasser. 1975. Comparative immunological relationships of two distinct sets of isofunctional dehydrogenases in the genus Leuconostoc. Int. J. Syst. Bacteriol. 25:1-6.

7. Hontebeyrie, M., and F. Gasser. 1977. Deoxyribonucleic acid homologies in the genus Leuconostoc. Int. J. Syst. Bacteriol. 27:9-14.

8. Johnson, J. L., C. F. Phelps, C. S. Cummins, J. London, and F. Gasser. 1980. Taxonomy of the Lactobacillus acidophilus group. Int. J. Syst. Bacteriol. 30:53-68.

9. Lapage, S. P., P. H. A. Sneath, E. F. Lessel, V. B. D. Skerman, H. P. R. Seeliger, and W. A. Clark (ed.). 1975. International code of nomenclature of bacteria. 1975 Revision. American Society for Microbiology, Washington, D.C.

10. Lauer, E., C. Helming, and O. Kandler. 1980. Heterogeneity of the species Lactobacillus acidophilus (Moro) Hansen and Mocquot as revealed by biochemical characteristics and DNA/DNA hybridization. Zentralbl. Bakteriol. Parasitenkd. Infektionskr. Hyg. Abt. 1 Orig. Reihe C 1:150-168.

11. Mays, T. D., L. V. Holdeman, W. E. C. Moore, M. Rogosa, and J. L. Johnson. 1982. Taxonomy of the genus Veillonella Prevot. Int. J. Syst. Bacteriol. 32:28-36.

12. Schleifer, K. H., R. Kilpper-Balz, U. Fischer, A. Faller, and J. Endl. 1982. Identification of "Micrococcus candidus" ATCC 14852 as a strain of "Staphylococcus epidermis" and of "Micrococcus caseolyticus" ATCC 13548 and Micrococcus varians ATCC 29750 as members of a new species, Staphylococcus caseolyticus. Int. J. Syst. Bacteriol. 32:15-20. 